\title{
Clinical implications of adipocytokines and newly emerging metabolic factors with relation to insulin resistance and cardiovascular health
}

\section{Sung Hee Choi *, Eun Shil Hong and Soo Lim*}

Department of Internal Medicine, Division Endocrinology and Metabolism, Seoul National University College of Medicine, Seoul National University Bundang Hospital, Seongnam, Korea

Edited by:

Tsuguhito Ota, Kanazawa University, Japan

\section{Reviewed by:}

Undurti Narasimha Das, UND LIfe

Sciences, USA

Carmine Grieco, Glenville State

College, USA

*Correspondence:

Sung Hee Choi and Soo Lim, Department of Internal Medicine,

Division Endocrinology and Metabolism, Seoul National

University College of Medicine, Seoul National University Bundang Hospital,

Gumidong 300, Seongnam,

Gyeonggi-do 463-737, Korea

e-mail:drshchoi@snu.ac.kr;

limsoo@snu.ac.kr

\begin{abstract}
Adipose tissue is known to secrete hormones actively and produces many biologically active proteins called adipocytokines. Typically, obesity is followed by low-grade inflammation, which is characterized by increased circulating levels of pro-inflammatory cytokines. Macrophages play a role in the inflammatory process by secreting many cytokines such as tumor necrosis factor alpha, interleukin-6, resistin, and retinol binding protein-4. These cytokines and chemokines participate in low-grade pro-inflammatory processes leading to insulin resistance, metabolic impairment, and cardiovascular diseases. More metabolic regulators, such as fibroblast growth factor (FGF)21, FGF19, FGF1, vaspin, and visfatin have now been discovered but their exact roles in human diseases are still unclear. This review focuses on recent research regarding the role of adipokines and new metabolic factors in metabolic derangement or cardiovascular disease.
\end{abstract}

Keywords: new cytokines, adiponectin, FGFs, biomarker, obesity, diabetes mellitus, insulin resistance

\section{INTRODUCTION}

The prevalence of obesity is increasing throughout the world. Obesity is associated with a broad spectrum of cardiometabolic disorders, including hypertension, dyslipidemia, diabetes, and cardiovascular disease (CVD) (1). Obesity is a heterogeneous disorder characterized by multifactorial etiology, which is characterized by various processes: changes in adipocytokines, activation of lowgrade inflammation, and production of reactive oxygen species. These factors are linked to endothelial dysfunction, oxidative stress, and inflammatory processes and finally lead to the development of atherosclerosis by multiple interactive pathways $(2,3)$.

Adipose tissue deposition shows distinct differences between different body areas. These include anatomical, cellular, molecular, physiological, clinical, and prognostic differences. Many studies have suggested that when compared with subcutaneous adipose tissue, visceral adipose tissue and other ectopic fats are more cellular, vascular, and innervated, with a larger number of inflammatory and immune cells, less pre-adipocyte differentiation, and a greater percentage of large adipocytes $(4,5)$.

As adiposity increases in visceral and ectopic areas, macrophages may increase infiltration (6). This cross-talk between adipose tissue and macrophages is a source of many cytokines such as tumor necrosis factor alpha (TNF $\alpha$ ), interleukin (IL)-6, resistin, retinol binding protein-4 (RBP4), which are suspected to participate in low-grade pro-inflammatory processes leading to metabolic disorders, insulin resistance, and CVDs (7). Other adipokines, such as visfatin and vaspin, have been discovered but their exact roles are still unknown. Emerging metabolic regulators such as fibroblast growth factor 21 (FGF21), other FGFs and myonectin appear to play roles in obesity and insulin resistance, from our experience. This review focuses on recent updates regarding the contribution of adipokines and newly discovered metabolic regulators to obesity and insulin resistance.

\section{ADIPONECTIN}

Adiponectin has attracted considerable attention among the many adipocytokines secreted from adipose tissue because of its insulinsensitizing property. Early studies showed that adiponectin levels were low in patients with impaired glucose homeostasis or type 2 diabetes $(8,9)$. Since then, many studies have demonstrated a significant inverse association between adiponectin and insulin resistance (9). Prospective studies have proved that low levels of adiponectin are associated with an increased incidence of type 2 diabetes $(10,11)$. Based on this finding, intervention studies focusing on exercise have been tried. A lifestyle intervention study with overweight/obese children for 1 year increased circulating adiponectin levels and insulin sensitivity significantly (12). Our group also proved that adiponectin levels increased significantly after a 10-week aerobic training program in healthy young and middle-aged women, and this was associated with improvements in insulin sensitivity (13).

Adiponectin is closely associated with atherogenesis and the development of CVDs. Low plasma adiponectin level was a predictor of CVD outcome such as myocardial infarction in the general population and among patients with diabetes or end-stage renal disease (14-17). Interestingly, several studies suggested that the 
high molecular weight form of adiponectin is a more accurate independent risk factor for CVD than the whole adiponectin level (17-19). However, no significant association between adiponectin and the risk of CVD was found after adjustment for potential confounders (11).

From mechanistic studies in endothelial cells, it was proved that adiponectin strongly inhibits the production of inflammatory cytokines and adhesion molecules, including ICAM-1, VCAM1, and E-selectin (19). Those results suggest that high levels of adiponectin play a role against the development of atherosclerosis and this has been confirmed in human studies $(20,21)$.

Thus, many basic and some population-based studies suggest that adiponectin might have a beneficial role in metabolic diseases and atherosclerosis, but some reports are less consistent. This might arise from differences between studies such as variations in populations, confounding factors (or lack thereof) and different isoforms of adiponectin (total vs. the high molecular weight form).

\section{RESISTIN}

Initially, resistin was discovered as an adipocytokine in animal models. It was suspected to link obesity with diabetes because it was produced mainly by adipocytes (22). By contrast, adipocytes seem to contribute only a small fraction of the resistin production in humans (23). Instead, inflammatory cells such as macrophages are considered the predominant source of circulating resistin (24).

Some studies have reported that resistin levels are increased in obese individuals $(25,26)$ while others have not $(27,28)$. Population-based studies have shown that resistin levels are associated with metabolic impairments and insulin resistance $(27,29$, 30) but the association between resistin levels and insulin sensitivity has been inconsistent in humans $(25,31)$. Resistin levels have also been associated with coronary heart diseases (32) and were correlated with calcification deposition in coronary arteries (28, 33). In contrast, other studies have not shown a significant association between resistin and coronary artery diseases $(18,34)$. Thus, the evidence linking resistin with decreased insulin sensitivity or increased cardiovascular risk remains inconsistent.

Of note, the secretions of TNF $\alpha$, IL- 6 , and other cell adhesion molecules are increased by resistin (35). An in vitro study demonstrated that resistin treatment increased the proliferation and migration of vascular smooth muscle and endothelial cells (36). In summary, resistin may participate in cardiovascular physiopathology in humans via the action of macrophages implicated in the inflammatory response related to obesity.

\section{RETINOL BINDING PROTEIN-4}

Decades ago, RBP4 was discovered as an adipocytokine that binds specifically to vitamin A (37). RBP4 is produced mainly by the liver and adipose tissue (38). RBP4 levels are closely associated with obesity, particularly visceral adiposity in mice and humans (38, 39). Elevated RBP4 levels were associated with a clustering of components of metabolic syndrome in insulin-resistant subjects (39). In population-based studies, RBP4 levels were positively associated with the obesity index, high blood pressure, and unfavorable lipid profiles (40). RBP4 levels were increased in naive hypertensive women and were correlated with the degree of intima-media thickness, suggesting a participation of this adipocytokine in modulation of the atherosclerotic process and cardio- and cerebrovascular diseases $(41,42)$. Our group published data showing that regular exercise intervention with a 10-week, moderate-intensity regimen improved cardiorespiratory fitness and adipocytokines including RBP4 levels (13). Weight loss induced by bariatric surgery also decreased RBP4 concentrations (43). In addition, our group also reported that plasma RBP4 levels were significantly higher among patients converting to full diabetes mellitus (DM) from previous gestational DM compared with non-DM converters (44) and plasma RBP4 levels showed significant correlation with cardiovascular risks in patients with subclinical hypothyroidism (45). A recent study with dyslipidemia subjects found that circulating RBP4 concentrations were associated with small dense low-density lipoprotein (LDL) cholesterol and oxidized LDL levels (46).

Although there was robust evidence suggesting role of RBP4 in abnormal glucose metabolism and development of atherosclerosis in mice, several human studies reported that the serum level of RBP4 was not associated with obesity or insulin sensitivity $(47,48)$. Janke et al. reported discrepancy of relationship of RBP4 with glucose homeostasis between rodents and human (47). Promintzer et al. also demonstrated no increase of plasma RBP4 levels and no correlation with insulin sensitivity in insulin-resistant humans (48).

Since evidence showing relationship of RBP4 with cardiometabolic risk in human is inconsistent, there is still argument on whether elevated RBP4 levels contribute to the pathogenesis of abnormal glucose homeostasis or insulin resistance. More data are needed to clarify the potential role of RBP4 in abnormal metabolic consequences.

\section{C1q TUMOR NECROSIS FACTOR- $\alpha$-RELATED PROTEIN ISOFORM 5}

The C1q TNF- $\alpha$-related proteins or myonectins have drawn recent attention and C1q TNF- $\alpha$-related protein isoform 5 (C1QTNF5) has been a focus of research because of its possible association with cardiometabolic risk (49). Structurally, C1QTNF5 is similar to adiponectin in its domain structure. C1QTNF5 belongs to a family of proteins characterized by an N-terminal signal peptide, a collagen repeat domain, and a C-terminal C1q-like globular domain (50). C1QTNFs are expressed in many tissues and have more structural or extracellular matrix-related functions than adiponectin (51). Recently, it was found that the C1QTNF5 level increased in mitochondrial (mt) DNA-depleted myocytes and this was associated with elevated adenosine monophosphate-activated protein kinase (AMPK) activity. In addition, the serum level of C1QTNF5 increased significantly in obese/diabetic animals (52). C1QTNF5 gene was upregulated from the microarray result of subcutaneous fat in obese Pima Indians, suggesting its possible role in developing obesity (53). Our group found that a 10 -week exercise training program performed at moderate-intensity decreased C1QTNF5 levels and insulin resistance parameters and increased cardiorespiratory fitness, mtDNA density, and adiponectin level in both young and older groups of women (54). These findings suggest that C1QTNF5 might be an important factor linking mitochondrial dysfunction with insulin resistance. Further research is needed 


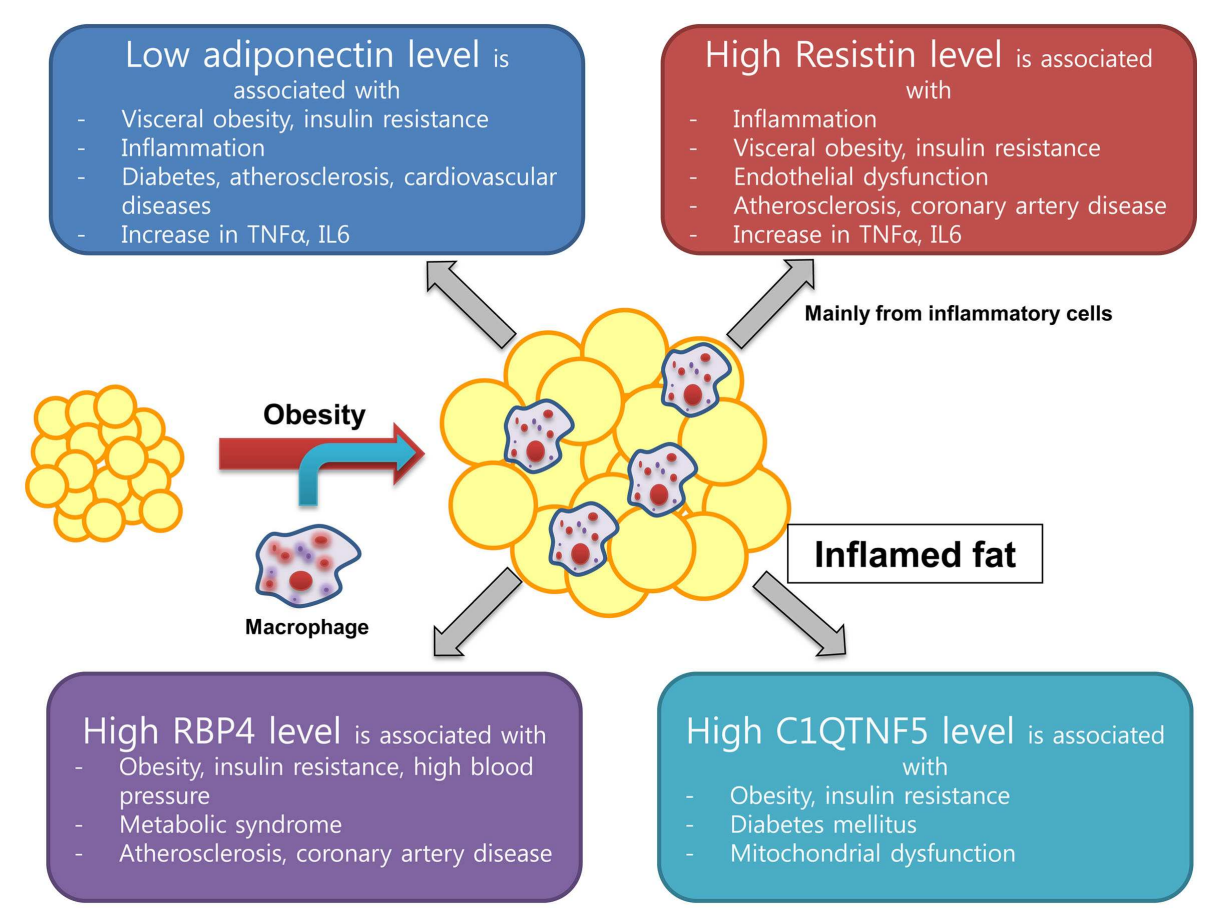

FIGURE 1 | New emerging adipokine from inflamed fat and its association with insulin resistance and cardiovascular health.

to identify the role and molecular mechanism of C1QTNF5 in the development of insulin resistance. Integrated schematic figure from adiponectin to C1QTNF is in Figure 1.

\section{FIBROBLAST GROWTH FACTOR 21}

Fibroblast Growth Factor (FGF)21, FGF19, and FGF23 belong to the FGF19 family that acts in hormone-like manners unlike other FGF species (55). FGF21 has been highlighted as a new drug candidate for enhancing insulin sensitivity, inducing lipolysis, and preventing diet-induced obesity in many in vitro and in vivo studies (56-58). FGF21 is mainly produced in the liver but acts on adipose tissue due to its preference for binding to FGF receptor $1(55,59)$. In humans, serum FGF21 levels are paradoxically increased in metabolic diseases such as obesity, diabetes, and CVD (60-62), which infer FGF21 resistance in humans. There are several lines of evidence from animal studies to explain FGF21 resistance in the receptor and in the post-receptor signaling pathway but there is no clear mechanism in humans so far. Including the results of our group, FGF21 excretion in humans is dependent on residual renal function based on data from patients in end-stage renal disease undergoing peritoneal dialysis and hemodialysis $(63,64)$. We reported that serum FGF21 concentration was significantly associated with altered lipid profiles, especially with hypertriglyceridaemia, insulin resistance, metabolic syndrome, and ectopic fat deposition when adjusted for the body mass index (65). Recently, many interesting features about the role of FGF21 in metabolism have been published. FGF21 regulates PGC1- $\alpha$ protein levels and enhances white adipose tissue browning with upregulation of UCP1 and other thermogenic genes in a cold-exposure mouse model (66). Kim et al. reported that muscle-specific deletion of the Atg7 (autophagy-related 7) gene in mice produced mitochondrial dysfunction and promoted FGF21 expression, showing a phenotype of being insulin-sensitive and resistant to diet-induced obesity (67). FGF21 enhanced peroxisome proliferator-activated receptor gamma (PPAR $\gamma$ ) desumoylation in fat cells to increase its action and showed association with lower bone mass caused by $\operatorname{PPAR} \gamma$ activation in vivo $(68,69)$. There are still many unknown aspects of FGF21, especially its role in human metabolism. However, clinical trials of this molecule are ongoing and the results will help explain its effect on glucose, obesity, and lipid metabolism in humans more clearly.

\section{OTHER FGFs}

FGF19 in humans and its mouse ortholog FGF15 have been studied for their roles in controlling bile acid synthesis. Recent data showed that activation of the farnesoid X receptor (FXR) by bile acids induced FGF19 and FGF receptor 4-mediated JNK/ERK pathways and inhibited the CY7A1 gene encoding cholesterol $7 \alpha$ hydroxylase (70). In other study, transintestinal flux of bile acids with diurnal variation to control FGF19 formation in the intestine (71). The peak FGF19 formation was made $90-120$ min after postprandial rise of serum bile acids. FGF19 is also a member of the FGF19 family, like FGF21 and FGF23, and acts in a hormone-like manner with a possible role in cholesterol metabolism through bile acid synthesis. In addition, FGF1 has a role in adipose tissue remodeling in mice fed a high-fat diet, being regulated by PPAR $\gamma$ activation. Mice lacking FGF1 showed abnormal adipose tissue with aberrant vasculature and a severe diabetic phenotype in high-fat dietary conditions (72). FGF1 is known for its role in wound healing and development (73), but it is now seen to have a 


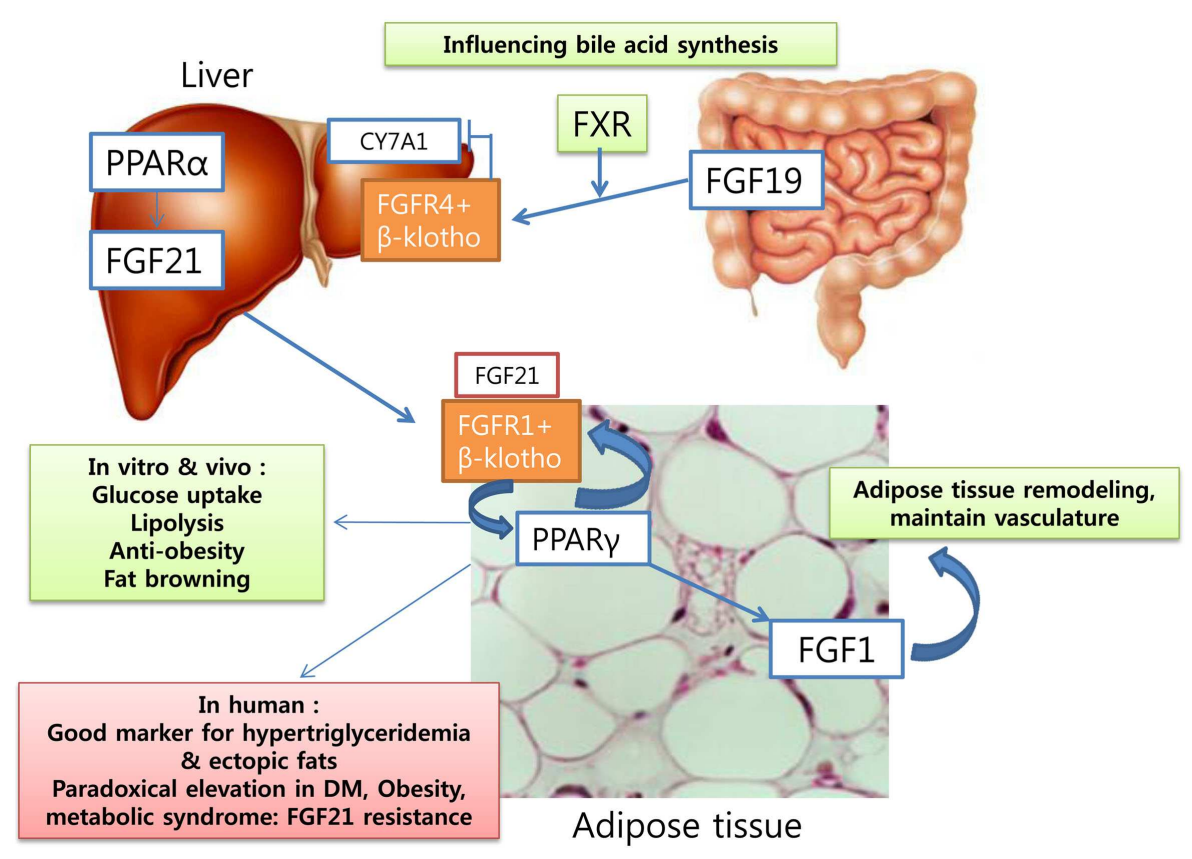

FIGURE 2 | Fibroblast growth factors: as metabolic regulators in human.

role in adipose tissue remodeling and a possible link with obesity. The possible role of FGF 19 family in human is in Figure 2.

\section{VASPIN}

Vaspin is an adipocytokine isolated from visceral adipose tissue of an animal model of abdominal obesity with type 2 diabetes (OLETF rat). It is increased in the prediabetic stage and decreases when the OLETF rats develop overt diabetes. In animals, vaspin treatment ameliorates insulin sensitivity in high-fator high sucrose-induced diabetes models (74) and protects against endothelial cell damage caused by free fatty acids through the PI3 kinase/Akt pathway (75). It has been suggested to be a "good" adipocytokine, such as adiponectin. However, serum vaspin levels were paradoxically elevated in human subjects with diabetes and obesity (76). We also reported that the serum vaspin level was higher in women than in men and it was correlated with the metabolic syndrome in men and coronary atherosclerosis in women. However, men with longer duration of diabetes and microvascular complications showed significantly lower levels of vaspin (77). More data are needed to understand the role of vaspin in human diseases such as atherosclerosis, diabetes, and obesity.

\section{VISFATIN}

Visfatin was first isolated from the visceral fat of humans and mice and showed insulin-like action by binding to the insulin receptor (78). In carotid artery atheromatous plaques, immunohistochemistry for visfatin showed much higher expression in unstable, symptomatic patients compared with asymptomatic patients, suggesting a role in generating macrophage foam cells in atheromata (79). The serum visfatin level was significantly reduced after gastric bypass surgery in morbidly obese subjects (80). Because visfatin is a pre B cell colony-enhancing factor, it has been studied in modulating systemic inflammation. In CD14+ monocytes, visfatin induced the expression of IL- $1 \beta$, TNF- $\alpha$, IL- 6 , and other CD molecules (81). In addition, the serum visfatin level was higher in patients with diabetes and diabetic nephropathy (82). Visfatin is now regarded as an extracellular nicotinamide phosphoribosyltransferase (eNampt) enzyme and plays an important role in insulin secretion from pancreatic $\beta$ cell by systemic nicotinamide adenine dinucleotide (NAD) biosynthesis (83). In vitro and in vivo, visfatin mimics insulin action, but in human studies, it is paradoxically increased in disease conditions and shows correlation with systemic inflammation, vascular complications, and insulin secretion. However, more studies are needed to clarify the role of visfatin in humans.

\section{CONCLUSION}

In summary, adipose and muscle tissues are now recognized as important and active endocrine organs. More adipocytokines and metabolic regulators are being discovered continuously and the clinical implications of these molecules are important in understanding the pathophysiology of human obesity, insulin resistance, and CVD. The "classic" adipocytokines such as adiponectin, TNF$\alpha$, and IL- 6 have been regarded as consistent surrogate markers to reflect cardiovascular risk and other metabolic abnormalities in subjects with insulin resistance. Adiponectin was considered as a good biomarker to protect atherosclerosis and to reduce systemic inflammation from many studies that we mentioned in this review. However, recent studies suggested so called "adiponectin paradox" in many studies, which showed increased adiponectin levels were correlated with higher cardiovascular or all-cause mortality in epidemiological data (84-86). The underlying mechanism behind 
this paradox is still unclear, but we can assume that there could some compensatory elevation of adiponectin in patients with metabolic abnormalities resulted in the association with higher mortality in the future.

Some evidence provides linking resistin and RBP4 with insulin resistance or cardiovascular risk. However, there are inconsistent results suggesting no or weak relationship of these factors with obesity and insulin sensitivity. For example, RBP4 was discovered from adipose tissue specific GLUT4 knockout mouse to explain strong insulin resistance in this animal model. However, the inconsistent association with insulin resistance parameters in different clinical settings of various studies which included patients with obesity, DM, different ethnicity, and CVD, it could not convince us to believe the role of RBP4 would be a causality of insulin resistance in metabolic diseases.

As for the emerging metabolic regulators such as FGFs (FGF21, FGF19, and FGF1), adipokines from visceral fat (vaspin and visfatin) and myokines, we need more studies to clarify their role in human diseases. FGF21 has been developed as a new drug for

\section{REFERENCES}

1. Ogden CL, Carroll MD, Curtin LR, McDowell MA, Tabak CJ, Flegal KM. Prevalence of overweight and obesity in the United States, 19992004. JAMA (2006) 295:1549-55. doi:10.1001/jama.295.13.1549

2. Bastard J-P, Maachi M, Lagathu C, Kim MJ, Caron M, Vidal H, et al. Recent advances in the relationship between obesity, inflammation, and insulin resistance. Eur Cytokine Netw (2006) 17:4-12.

3. Shoelson SE, Herrero L, Naaz A. Obesity, inflammation, and insulin resistance. Gastroenterology (2007) 132:2169. doi:10.1053/j. gastro.2007.03.059

4. Kahn BB, Flier JS. Obesity and insulin resistance. J Clin Invest (2000) 106:473-81. doi:10.1172/ JCI10842

5. Lumeng CN, Bodzin JL, Saltiel AR. Obesity induces a phenotypic switch in adipose tissue macrophage polarization. J Clin Invest (2007) 117:175-84. doi:10.1172/JCI29881

6. Harman-Boehm I, Blüher M, Redel $\mathrm{H}$, Sion-Vardy N, Ovadia S, Avinoach E, et al. Macrophage infiltration into omental versus subcutaneous fat across different populations: effect of regional adiposity and the comorbidities of obesity. J Clin Endocrinol Metab (2007) 92:2240-7. doi:10.1210/jc. 2006-1811

7. Bahceci M, Gokalp D, Bahceci S, Tuzcu A, Atmaca S, Arikan S. The correlation between adiposity and adiponectin, tumor necrosis factor alpha, interleukin- 6 and high sensitivity $\mathrm{C}$-reactive protein levels. Is adipocyte size associated with inflammation in adults? J Endocrinol Invest (2007) 30:210.

8. Hu E, Liang $\mathrm{P}$, Spiegelman BM. AdipoQ is a novel adipose-specific gene dysregulated in obesity. J Biol Chem (1996) 271:10697-703. doi: 10.1074/jbc.271.18.10697

9. Hotta K, Funahashi T, Arita Y, Takahashi M, Matsuda M, Okamoto $\mathrm{Y}$, et al. Plasma concentrations of a novel, adipose-specific protein, adiponectin, in type 2 diabetic patients. Arterioscler Thromb Vasc Biol (2000) 20:1595-9. doi:10.1161/ 01.ATV.20.6.1595

10. Li S, Shin HJ, Ding EL, van Dam RM. Adiponectin levels and risk of type 2 diabetes: a systematic review and meta-analysis. JAMA (2009) 302:179-88. doi:10. 1001/jama.2009.976

11. Karakas M, Zierer A, Herder C, Baumert J, Meisinger C, Koenig W, et al. Leptin, adiponectin, their ratio and risk of Coronary Heart Disease: results from the MONICA/KORA Augsburg Study 1984-2002. Atherosclerosis (2010) 209:220-5. doi:10. 1016/j.atherosclerosis.2009.08.020

12. Cambuli VM, Musiu MC, Incani M, Paderi M, Serpe R, Marras V, et al. Assessment of adiponectin and leptin as biomarkers of positive metabolic outcomes after lifestyle intervention in overweight and obese children. J Clin Endocrinol Metab (2008) 93:3051-7. doi:10.1210/jc. 2008-0476

13. Lim S, Choi SH, Jeong IK, Kim JH, Moon MK, Park KS, et al. Insulinsensitizing effects of exercise on adiponectin and retinol binding

antidiabetic medication and human trial is on-going based on its favorable results from in vitro and in vivo. We have to wait and see the result of human trials that we could fully understand the mechanism of antidiabetic or any metabolic effects on human body. The possible role of FGF21 through PPAR $\alpha$ and $\gamma$ in the liver and in fat tissues can be expected to have beneficial effects on insulin signaling pathway to ameliorate metabolic abnormalities. It is still a question whether these new metabolic regulators are just surrogate markers or might be causes of obesity and insulin resistance.

From this perspective, it is too early yet to apply these adipocytokines or metabolic regulators as predictors for cardiometabolic risk in the clinical practice. Up to date, it could be used as a surrogate biomarker to reflect metabolic abnormalities in many metabolic diseases. More mechanistic experiments and long-term outcome studies are warranted to elucidate the active role of these factors in the physiopathology of cardiometabolic disorders to identify their clinical implications at bedside level.

protein- 4 concentrations in young and middle-aged women. J Clin Endocrinol Metab (2008) 93:22638. doi:10.1210/jc.2007-2028

14. Pischon T, Girman CJ, Hotamisligil GS, Rifai N, Hu FB, Rimm EB. Plasma adiponectin levels and risk of myocardial infarction in men. JAMA (2004) 291:1730-7. doi:10. 1001/jama.291.14.1730

15. Zoccali C, Mallamaci F, Tripepi G, Benedetto FA, Cutrupi S, Parlongo $\mathrm{S}$, et al. Adiponectin, metabolic risk factors, and cardiovascular events among patients with end-stage renal disease. J Am Soc Nephrol (2002) 13:134-41.

16. Costacou T, Zgibor JC, Evans RW, Otvos J, Lopes-Virella MF, Tracy $\mathrm{RP}$, et al. The prospective association between adiponectin and coronary artery disease among individuals with type 1 diabetes. The Pittsburgh Epidemiology of Diabetes Complications Study. Diabetologia (2005) 48:41-8. doi:10. 1007/s00125-004-1597-y

17. Koenig W, Khuseyinova N, Baumert J, Meisinger C, Lowel H. Serum concentrations of adiponectin and risk of type 2 diabetes mellitus and coronary heart disease in apparently healthy middle-aged men: results from the 18-year followup of a large cohort from southern Germany. J Am Coll Cardiol (2006) 48:1369-77. doi:10.1016/j. jacc.2006.06.053

18. Lim S, Koo BK, Cho SW, Kihara S, Funahashi T, Cho YM, et al. Association of adiponectin and resistin with cardiovascular events in Korean patients with type 2 diabetes: the Korean atherosclerosis study (KAS): a 42-month prospective study. Atherosclerosis (2008) 196:398-404. doi:10.1016/j. atherosclerosis.2006.11.017

19. Motoshima H, Wu X, Mahadev K, Goldstein BJ. Adiponectin suppresses proliferation and superoxide generation and enhances eNOS activity in endothelial cells treated with oxidized LDL. Biochem Biophys Res Commun (2004) 315:264-71. doi:10.1016/j.bbrc.2004.01.049

20. Lindberg S, Mogelvang R, Pedersen SH, Bjerre M, Frystyk J, Flyvbjerg A, et al. Relation of serum adiponectin levels to number of traditional atherosclerotic risk factors and all-cause mortality and major adverse cardiovascular events (from the Copenhagen City Heart Study). Am J Cardiol (2013) 111:1139-45. doi:10.1016/j. amjcard.2012.12.043

21. Huang SS, Huang $\mathrm{PH}$, Chen $\mathrm{YH}$, Chiang KH, Chen JW, Lin SJ. Association of adiponectin with future cardiovascular events in patients after acute myocardial infarction. $J$ Atheroscler Thromb (2010) 17:295303. doi:10.5551/jat.3533

22. Steppan CM, Bailey ST, Bhat S, Brown EJ, Banerjee RR, Wright CM, et al. The hormone resistin links obesity to diabetes. Nature (2001) 409:307-12. doi:10.1038/35053000

23. Fain JN, Cheema PS, Bahouth SW, Lloyd HM. Resistin release by human adipose tissue explants in primary culture. Biochem Biophys Res Commun (2003) 300:674-8. doi: 10.1016/S0006-291X(02)02864-4 
24. Patel L, Buckels AC, Kinghorn IJ, Murdock PR, Holbrook JD, Plumpton $\mathrm{C}$, et al. Resistin is expressed in human macrophages and directly regulated by PPAR gamma activators. Biochem Biophys Res Commun (2003) 300:472-6. doi: 10 . 1016/S0006-291X(02)02841-3

25. Gerber M, Boettner A, Seidel B, Lammert A, Bar J, Schuster E, et al. Serum resistin levels of obese and lean children and adolescents: biochemical analysis and clinical relevance. J Clin Endocrinol Metab (2005) 90:4503-9. doi:10.1210/jc. 2005-0437

26. Savage DB, Sewter CP, Klenk ES, Segal DG, Vidal-Puig A, Considine RV, et al. Resistin/Fizz3 expression in relation to obesity and peroxisome proliferator-activated receptor-gamma action in humans. Diabetes (2001) 50:2199-202. doi:10.2337/diabetes.50.10.2199

27. McTernan PG, Fisher FM, Valsamakis G, Chetty R, Harte A, McTernan CL, et al. Resistin and type 2 diabetes: regulation of resistin expression by insulin and rosiglitazone and the effects of recombinant resistin on lipid and glucose metabolism in human differentiated adipocytes. J Clin Endocrinol Metab (2003) 88:6098106. doi:10.1210/jc.2003-030898

28. Reilly MP, Lehrke M, Wolfe ML, Rohatgi A, Lazar MA, Rader DJ. Resistin is an inflammatory marker of atherosclerosis in humans. Circulation (2005) 111:932-9. doi:10. 1161/01.CIR.0000155620.10387.43

29. Hivert MF, Sullivan LM, Fox CS, Nathan DM, D'Agostino RBSr., Wilson PW, et al. Associations of adiponectin, resistin, and tumor necrosis factor-alpha with insulin resistance. J Clin Endocrinol Metab (2008) 93:3165-72. doi:10.1210/jc. 2008-0425

30. Norata GD, Ongari M, Garlaschelli K, Raselli S, Grigore L, Catapano AL. Plasma resistin levels correlate with determinants of the metabolic syndrome. Eur J Endocrinol (2007) 156:279-84. doi:10.1530/eje. 1.02338

31. Mojiminiyi OA, Abdella NA. Associations of resistin with inflammation and insulin resistance in patients with type 2 diabetes mellitus. Scand J Clin Lab Invest (2007) 67:215-25. doi:10.1080/00365510601032532

32. Pischon T, Bamberger CM, Kratzsch J, Zyriax BC, Algenstaedt P, Boeing $\mathrm{H}$, et al. Association of plasma resistin levels with coronary heart disease in women. Obes Res (2005)
13:1764-71. doi:10.1038/oby.2005. 215

33. Frankel DS, Vasan RS, D'Agostino RBSr., Benjamin EJ, Levy D, Wang TJ, et al. Resistin, adiponectin, and risk of heart failure the Framingham offspring study. J Am Coll Cardiol (2009) 53:754-62. doi:10.1016/ j.jacc.2008.07.073

34. Yaturu S, Daberry RP, Rains J, Jain S. Resistin and adiponectin levels in subjects with coronary artery disease and type 2 diabetes. Cytokine (2006) 34:219-23. doi:10. 1016/j.cyto.2006.05.005

35. Bokarewa M, Nagaev I, Dahlberg L, Smith U, Tarkowski A. Resistin, an adipokine with potent proinflammatory properties. I Immunol (2005) 174:5789-95.

36. Calabro P, Samudio I, Willerson JT, Yeh ET. Resistin promotes smooth muscle cell proliferation through activation of extracellular signal-regulated kinase $1 / 2$ and phosphatidylinositol 3kinase pathways. Circulation (2004) 110:3335-40. doi:10.1161/01.CIR. 0000147825.97879.E7

37. Quadro L, Blaner WS, Salchow DJ, Vogel S, Piantedosi R, Gouras P, et al. Impaired retinal function and vitamin A availability in mice lacking retinol-binding protein. $E M B O$ J (1999) 18:4633-44. doi:10.1093/ emboj/18.17.4633

38. Yang Q, Graham TE, Mody N, Preitner F, Peroni OD, Zabolotny JM, et al. Serum retinol binding protein 4 contributes to insulin resistance in obesity and type 2 diabetes. Nature (2005) 436:356-62. doi:10.1038/nature03711

39. Graham TE, Yang Q, Bluher M, Hammarstedt A, Ciaraldi TP, Henry $\mathrm{RR}$, et al. Retinol-binding protein 4 and insulin resistance in lean, obese, and diabetic subjects. $N E n g l$ J Med (2006) 354:2552-63. doi:10. 1056/NEJMoa054862

40. Meisinger C, Ruckert IM, Rathmann W, Doring A, Thorand B, Huth C, et al. Retinol-binding protein 4 is associated with prediabetes in adults from the general population: the Cooperative Health Research in the Region of Augsburg (KORA) F4 Study. Diabetes Care (2011) 34:1648-50. doi:10. 2337/dc11-0118

41. Solini A, Santini E, Madec S, Rossi C, Muscelli E. Retinol-binding protein-4 in women with untreated essential hypertension. Am J Hypertens (2009) 22:1001-6. doi:10.1038/ ajh.2009.116

42. Ingelsson E, Sundstrom J, Melhus $\mathrm{H}$, Michaelsson $\mathrm{K}$, Berne $\mathrm{C}$,
Vasan RS, et al. Circulating retinolbinding protein 4, cardiovascular risk factors and prevalent cardiovascular disease in elderly. Atherosclerosis (2009) 206:239-44. doi:10.1016/ j.atherosclerosis.2009.02.029

43. Haider DG, Schindler K, Prager G, Bohdjalian A, Luger A, Wolzt $M$, et al. Serum retinol-binding protein 4 is reduced after weight loss in morbidly obese subjects. J Clin Endocrinol Metab (2007) 92:116871. doi:10.1210/jc.2006-1839

44. Choi SH, Kwak SH, Youn B-S, Lim S, Park YJ, Lee $\mathrm{H}$, et al. High plasma retinol binding protein4 and low plasma adiponectin concentrations are associated with severity of glucose intolerance in women with previous gestational diabetes mellitus. J Clin Endocrinol Metab (2008) 93:3142-8. doi:10. 1210/jc.2007-1755

45. Choi SH, Lee YJ, Park YJ, Kim KW, Lee EJ, Lim S, et al. Retinol binding protein-4 elevation is associated with serum thyroid-stimulating hormone level independently of obesity in elderly subjects with normal glucose tolerance. J Clin Endocrinol Metab (2008) 93:23138. doi:10.1210/jc.2007-2536

46. Wu J, Shi YH, Niu DM, Li HQ, Zhang CN, Wang JJ. Association among retinol-binding protein 4, small dense LDL cholesterol and oxidized LDL levels in dyslipidemia subjects. Clin Biochem (2012) 45:619-22. doi:10.1016/j. clinbiochem.2012.02.022

47. Janke J, Engeli S, Boschmann M, Adams F, Bohnke J, Luft FC, et al. Retinol-binding protein 4 in human obesity. Diabetes (2006) 55:280510. doi:10.2337/db06-0616

48. Promintzer M, Krebs M, Todoric J, Luger A, Bischof MG, Nowotny P, et al. Insulin resistance is unrelated to circulating retinol binding protein and protein $\mathrm{C}$ inhibitor. J Clin Endocrinol Metab (2007) 92:430612. doi:10.1210/jc.2006-2522

49. Schaffler A, Buechler C. CTRP family: linking immunity to metabolism. Trends Endocrinol Metab (2012) 23:194-204. doi:10.1016/j. tem.2011.12.003

50. Wong GW, Krawczyk SA Kitidis-Mitrokostas C, Revett T, Gimeno R, Lodish HF. Molecular, biochemical and functional characterizations of $\mathrm{Clq} / \mathrm{TNF}$ family members: adipose-tissueselective expression patterns, regulation by PPAR-gamma agonist, cysteine-mediated oligomerizations, combinatorial associations and metabolic functions.
Biochem J (2008) 416:161-77. doi:10.1042/BJ20081240

51. Tom Tang $\mathrm{Y}, \mathrm{Hu} \mathrm{T}$, Arterburn M, Boyle B, Bright JM, Palencia $\mathrm{S}$, et al. The complete complement of C1q-domain-containing proteins in Homo sapiens. Genomics (2005) 86:100-11. doi:10.1016/j. ygeno.2005.03.001

52. Park SY, Choi JH, Ryu HS, Pak YK, Park KS, Lee HK, et al. $\mathrm{Clq}$ tumor necrosis factor alpha-related protein isoform 5 is increased in mitochondrial DNAdepleted myocytes and activates AMP-activated protein kinase. J Biol Chem (2009) 284:27780-9. doi:10. 1074/jbc.M109.005611

53. Lee YH, Nair S, Rousseau E, Allison DB, Page GP, Tataranni PA, et al. Microarray profiling of isolated abdominal subcutaneous adipocytes from obese vs non-obese Pima Indians: increased expression of inflammation-related genes. Diabetologia (2005) 48:1776-83. doi: 10.1007/s00125-005-1867-3

54. Lim S, Choi SH, Koo BK, Kang $\mathrm{SM}$, Yoon JW, Jang $\mathrm{HC}$, et al. Effects of aerobic exercise training on $\mathrm{Clq}$ tumor necrosis factor alpha-related protein isoform 5 (myonectin): association with insulin resistance and mitochondrial DNA density in women. J Clin Endocrinol Metab (2012) 97:E8893. doi:10.1210/jc.2011-1743

55. Kharitonenkov A, Shiyanova TL, Koester A, Ford AM, Micanovic R, Galbreath EJ, et al. FGF-21 as a novel metabolic regulator. J Clin Invest (2005) 115:1627-35. doi:10. 1172/JCI23606

56. Badman MK, Pissios P, Kennedy AR, Koukos G, Flier JS, MaratosFlier E. Hepatic fibroblast growth factor 21 is regulated by PPAR $\alpha$ and is a key mediator of hepatic lipid metabolism in ketotic states. Cell Metab (2007) 5:426-37. doi:10. 1016/j.cmet.2007.05.002

57. Coskun T, Bina HA, Schneider MA, Dunbar JD, Hu CC, Chen Y, et al. Fibroblast growth factor 21 corrects obesity in mice. Endocrinology (2008) 149:6018-27. doi:10.1210/ en.2008-0816

58. Arner P, Pettersson A, Mitchell PJ, Dunbar JD, Kharitonenkov A, Rydén M. FGF21 attenuates lipolysis in human adipocytes - a possible link to improved insulin sensitivity. FEBS Lett (2008) 582:1725-30. doi:10.1016/j.febslet. 2008.04 .038

59. Nishimura T, Nakatake Y, Konishi $\mathrm{M}$, Itoh $\mathrm{N}$. Identification of a novel FGF, FGF-21, preferentially 
expressed in the liver. Biochim Biophys Acta (2000) 1492:2036. doi:10.1016/S0167-4781(00) 00067-1

60. Chen W, Li L, Yang G, Li K, Qi X, Zhu W, et al. Circulating FGF-21 levels in normal subjects and in newly diagnose patients with type 2 diabetes mellitus. Exp Clin Endocrinol Diabetes (2008) 116:65-8. doi:10.1055/ s-2007-985148

61. Eto K, Tumenbayar B, Nagashima S-I, Tazoe F, Miyamoto M, Takahashi M, et al. Distinct association of serum FGF21 or adiponectin levels with clinical parameters in patients with type 2 diabetes. Diabetes Res Clin Pract (2010) 89:52-7. doi:10. 1016/j.diabres

62. Zhang X, Yeung DC, Karpisek M, Stejskal D, Zhou ZG, Liu F, et al. Serum FGF21 levels are increased in obesity and are independently associated with the metabolic syndrome in humans. Diabetes (2008) 57:1246-53. doi:10. 2337/db07-1476

63. Han SH, Choi SH, Cho BJ, Lee Y, Lim S, Park YJ, et al. Serum fibroblast growth factor-21 concentration is associated with residual renal function and insulin resistance in end-stage renal disease patients receiving long-term peritoneal dialysis. Metabolism (2010) 59:1656-62. doi:10.1016/j.metabol. 2010.03.018

64. Stein S, Bachmann A, Lössner U, Kratzsch J, Blüher M, Stumvoll M, et al. Serum levels of the adipokine FGF21 depend on renal function. Diabetes Care (2009) 32:126-8. doi: $10.2337 / \mathrm{dc} 08-1054$

65. Lee Y, Lim S, Hong ES, Kim JH, Moon MK, Chun EJ, et al. Serum FGF21 concentration is associated with hypertriglyceridaemia, hyperinsulinaemia and pericardial fat accumulation, independently of obesity, but not with current coronary artery status. Clin Endocrinol (Oxf) (2012) doi:10. 1111/cen.12134. [Epub ahead of print].

66. Fisher FM, Kleiner S, Douris N, Fox EC, Mepani RJ, Verdeguer F, et al. FGF21 regulates PGC-1alpha and browning of white adipose tissues in adaptive thermogenesis. Genes Dev (2012) 26:271-81. doi:10.1101/gad. 177857.111
67. Kim KH, Jeong YT, Oh H, Kim SH, Cho JM, Kim YN, et al. Autophagy deficiency leads to protection from obesity and insulin resistance by inducing Fgf21 as a mitokine. Nat Med (2013) 19:83-92. doi:10.1038/ nm.3014

68. Wei W, Dutchak PA, Wang X, Ding $\mathrm{X}$, Wang $\mathrm{X}$, Bookout AL, et al. Fibroblast growth factor 21 promotes bone loss by potentiating the effects of peroxisome proliferatoractivated receptor $\gamma$. Proc Natl Acad Sci U S A (2012) 109:3143-8. doi: 10.1073/pnas.1200797109

69. Dutchak PA, Katafuchi T, Bookout AL, Choi JH, Yu RT, Mangelsdorf DJ, et al. Fibroblast growth factor21 regulates PPAR $\gamma$ activity and the antidiabetic actions of thiazolidinediones. Cell (2012) 148:556-67. doi: 10.1016/j.cell.2011.11.062

70. Song KH, Li T, Owsley E, Strom S, Chiang JY. Bile acids activate fibroblast growth factor 19 signaling in human hepatocytes to inhibit cholesterol $7 \alpha$-hydroxylase gene expression. Hepatology (2009) 49:297305. doi:10.1002/hep.22627

71. Lundasen T, Galman C, Angelin B, Rudling M. Circulating intestinal fibroblast growth factor 19 has a pronounced diurnal variation and modulates hepatic bile acid synthesis in man. J Intern Med (2006) 260:530-6. doi:10.1111/j. 1365-2796.2006.01731.x

72. Jonker JW, Suh JM, Atkins AR, Ahmadian M, Li P, Whyte J, et al. A PPARgamma-FGF1 axis is required for adaptive adipose remodelling and metabolic homeostasis. Nature (2012) 485:391-4. doi:10.1038/nature 10998

73. Itoh N, Ornitz DM. Evolution of the Fgf and Fgfr gene families. Trends Genet (2004) 20:563-9. doi: 10.1016/j.tig.2004.08.007

74. Hida K, Wada J, Eguchi J, Zhang H, Baba M, Seida A, et al. Visceral adipose tissue-derived serine protease inhibitor: a unique insulinsensitizing adipocytokine in obesity. Proc Natl Acad Sci U S A (2005) 102:10610-5. doi:10.1073/ pnas.0504703102

75. Jung $\mathrm{CH}$, Lee WJ, Hwang JY, Seol SM, Kim YM, Lee YL, et al. Vaspin protects vascular endothelial cells against free fatty acid-induced apoptosis through a phosphatidylinositol 3-kinase/Akt pathway. Biochem Biophys Res Commun (2011) 413:264-9. doi:10. 1016/j.bbrc.2011.08.083

76. Youn BS, Kloting N, Kratzsch J, Lee N, Park JW, Song ES, et al. Serum vaspin concentrations in human obesity and type 2 diabetes. Diabetes (2008) 57:372-7. doi:10.2337/ db07-1045

77. Choi SH, Kwak SH, Lee Y, Moon MK, Lim S, Park YJ, et al. Plasma vaspin concentrations are elevated in metabolic syndrome in men and are correlated with coronary atherosclerosis in women. Clin Endocrinol (Oxf) (2011) 75:628-35. doi:10. 1111/j.1365-2265.2011.04095.x

78. Fukuhara A, Matsuda M, Nishizawa M, Segawa K, Tanaka M, Kishimoto $\mathrm{K}$, et al. Visfatin: a protein secreted by visceral fat that mimics the effects of insulin. Science (2005) 307:426-30. doi:10.1126/science. 1097243

79. Dahl TB, Yndestad A, Skjelland M, Øie E, Dahl A, Michelsen A, et al. Increased expression of visfatin in macrophages of human unstable carotid and coronary atherosclerosis possible role in inflammation and plaque destabilization. Circulation (2007) 115:972-80. doi:10.1161/CIRCULATIONAHA. 106.665893

80. Haider DG, Schindler K, Schaller G, Prager G, Wolzt M, Ludvik B. Increased plasma visfatin concentrations in morbidly obese subjects are reduced after gastric banding. J Clin Endocrinol Metab (2006) 91:1578-81. doi:10.1210/jc. 2005-2248

81. Moschen AR, Kaser A, Enrich B, Mosheimer B, Theurl M, Niederegger $\mathrm{H}$, et al. Visfatin, an adipocytokine with proinflammatory and immunomodulating properties. J Immunol (2007) $\mathbf{1 7 8}$ 1748-58.

82. Kang YS, Song HK, Lee MH, Ko GJ, Cha DR. Plasma concentration of visfatin is a new surrogate marker of systemic inflammation in type 2 diabetic patients. Diabetes Res Clin Pract (2010) 89:141-9. doi:10.1016/ j.diabres.2010.03.020

83. Revollo JR, Körner A, Mills KF, Satoh A, Wang T, Garten A, et al. Nampt/PBEF/visfatin regulates insulin secretion in $\beta$ cells as a systemic NAD biosynthetic enzyme. Cell Metab (2007) 6:363-75. doi:10. 1016/j.cmet.2007.09.003

84. Kistorp C, Faber J, Galatius S, Gustafsson F, Frystyk J, Flyvbjerg A, et al. Plasma adiponectin, body mass index, and mortality in patients with chronic heart failure. Circulation (2005) 112:1756-62. doi:10.1161/CIRCULATIONAHA. 104.530972

85. Cavusoglu E, Ruwende C, Chopra V, Yanamadala S, Eng C, Clark LT, et al. Adiponectin is an independent predictor of all-cause mortality, cardiac mortality, and myocardial infarction in patients presenting with chest pain. Eur Heart J (2006) 27:2300-9. doi:10.1093/ eurheartj/ehl153

86. Wannamethee SG, Whincup $\mathrm{PH}$, Lennon L, Sattar N. Circulating adiponectin levels and mortality in elderly men with and without cardiovascular disease and heart failure. Arch Intern Med (2007) 167:1510-7. doi:10.1001/archinte. 167.14.1510

Conflict of Interest Statement: The authors declare that the research was conducted in the absence of any commercial or financial relationships that could be construed as a potential conflict of interest.

Received: 11 May 2013; accepted: 26 July 2013; published online: 21 August 2013. Citation: Choi SH, Hong ES and Lim S (2013) Clinical implications of adipocytokines and newly emerging metabolic factors with relation to insulin resistance and cardiovascular health. Front. Endocrinol. 4:97. doi: 10.3389/fendo.2013.00097

This article was submitted to Diabetes, a section of the journal Frontiers in Endocrinology.

Copyright (c) 2013 Choi, Hong and Lim. This is an open-access article distributed under the terms of the Creative Commons Attribution License (CC BY). The use, distribution or reproduction in other forums is permitted, provided the original author(s) or licensor are credited and that the original publication in this journal is cited, in accordance with accepted academic practice. No use, distribution or reproduction is permitted which does not comply with these terms. 